(Jurnal Teknologi Komputer dan Sistem Informasi)

Februari 2021, Vol 1, No 1, Hlm. 1-7

Available online at http://jurnal.goretanpena.com/index.php/teknisi

\title{
IMPLEMENTASI PULSE WIDTH MODULATION (PWM) PADA SISTEM BLENDING KACANG MENGGUNAKAN SENSOR LOAD CELL BERBASIS MIKROKONTROLER
}

\author{
Danang Pratama \\ Sistem Komputer STMIK Triguna Dharma \\ Email: danangpratama@gmail.com
}

\begin{abstract}
Kacang merupakan biji-bijian yang sering dimanfaatkan sebagai bahan masakan, salah satunya saus kacang yang biasa disajikan sebagai saus pelengkap pecal, gado-gado dan siomay. Dalam proses pembuatannya, kacang mengalami proses penggorengan, penghalusan dan pencampuran dengan air. Pada umunya proses penghalusan dan pencampuran kacang dengan air dilakukan dengan tenaga manusia sehingga pedagang harus menyelesaikan penghalusan kacang lalu mengerjakan masakan lainnya. Sebagai solusi dari kendala tersebut diperlukan adanya sistem penghalusan dan pencampuran kacang dengan sehingga pedagang dapat mengerjakan pekerjaan lainnya sambil menunggu kacang halus dan tercampur dengan air. Pada sistem ini diterapkan teknik Pulse Width Modulation (PWM) sebagai pengatur kecepatan putar motor, dimana informasi berat beban kacang dalam wadah blender didapat melalui sensor Load Cell kemudian dikendalikan oleh Mikrokontroler Arduino Uno sebagai sistem kendali. Beberapa komponen pendukung sistem seperti LCD sebagai output penampil.
\end{abstract}

Keywords: Blending Kacang, Load Cell, Pulse Width Modulation (PWM), Arduino Uno

\begin{abstract}
Abstrak: Peanuts are seeds that are often used as a cooking ingredient, one of which is peanut sauce which is usually served as a complementary sauce for pecal, gado-gado and dumplings. In the manufacturing process, beans undergo a frying process, refining and mixing with water. In general, the process of grinding and mixing nuts with water is done by human labor, so traders have to finish grinding the beans and then work on other dishes. As a solution to this problem, it is necessary to have a system of grinding and mixing the beans so that traders can do other work while waiting for the beans to be smooth and mixed with water. In this system, the Pulse Width Modulation (PWM) technique is applied as a motor rotating speed regulator, where the weight information of the bean load in the blender container is obtained through the Load Cell sensor then controlled by the Arduino Uno Microcontroller as a control system. Some of the system's supporting components, such as the LCD as the output of the viewer.
\end{abstract}

Kata kunci: Peanut Blending, Load Cell, Pulse Width Modulation (PWM), Arduino Uno

\section{PENDAHULUAN}

Pecal, gado-gado dan siomay adalah beberapa makanan yang menggunakan kacang sebagai sausnya. Rasanya yang khas membuat para penikmatnya ketagihan. Selain mengenyangkan perut, makanan ini juga mengandung banyak manfaat bagi tubuh. Seperti zat besi, kalium, kalsium serta zat fosfor yang dapat kita peroleh dari sayur kangkung. Kemudian kita juga bisa memperoleh vitamin B untuk kulit, dan vitamin $\mathrm{K}$ untuk menjaga kekuatan rambut, Vitamin ini dapat kita ambil pada sayuran tauge yang kita konsumsi dari pecel. Selain menggunakan kacang sebagai bahan utama pembuatan sausnya. Ada banyak 
Februari 2021, Vol 1, No 1, Hlm. 1-7

Available online at http://jurnal.goretanpena.com/index.php/teknisi

bahan lain dan beberapa rempah khas Indonesia yang dicampur ke dalamnya, sehingga memiliki cita rasa asam, manis, pedas dan gurih. Cita rasa yang sangat digemari oleh seluruh masyarakat Indonesia.

Ada beberapa tahap yang dilakukan dalam pembuatan saus kacang, mulai dari pembersihan bahan dengan air yang mengalir, kemudian penggorengan kacang. Setelah kacang digoreng lalu kacang dihaluskan hingga halus. Selain kacang, beberapa bahan lain seperti cabai, bawang, dan daun jeruk purut juga digoreng kemudian dihaluskan hingga halus lalu dicampurkan dengan kacang yang sudah dihaluskan tadi. Aduk hingga seluruh bumbu merata, dan jangan lupa beri garam dan gula sebagai penambah rasa.

Pada umumnya penghalusan dan pencampuran kacang dengan dilakukan secara manual dengan menggunakan tenaga manusia. Walaupun sekarang para pedagang siomay sudah mulai menggunakan blender dalam menghaluskan dan mencampurkan kacang dengan air [1], tetapi tetap menggunakan orang untuk menentukan kehalusan kacang yang di blender. Penghalusan kacang dengan menggunakan blender memiliki kelebihan dan kekurangan. Kelebihannya antara lain mempercepat proses penghalusan dan pencampuran kacang dengan air dan menghemat waktu. Juga kekurangannya adalah rasa dari kacang yang dihaluskan tidak seenak dengan penghalusan sistem tradisional.

Walaupun prosesnya membutuhkan waktu yang sedikit lama dan membutuhkan tenaga untuk menghaluskan dan mencapurkannya dengan air.
Untuk mempermudah pedagang membuat saus kacang, maka diperlukan sistem yang digunakan sebagai penentu waktu penghalusan dan pencampuran kacang dengan air. Dalam hal ini akan diterapkan suatu teknik Pulse Width Modulation (PWM). PWM itu sendiri adalah suatu teknik modulasi dengan mengubah lebar pulsa (duty cylce) dengan nilai amplitudo dan frekuensi yang tetap [2]. Teknik ini yang akan menentukan kecepatan putar blender untuk penghalusan dan pencampuran kacang dengan air. System ini bekerja dengan mendeteksi volume atau banyaknya kacang pada wadah blender.

Untuk menentukan beban atau berat kacang dalam wadah blender menggunakan sensor Load Cell [3]. Sensor yang mengubah gaya menjadi sinyal listrik. Kemudian sinyal akan dikirim ke Mikrokontoler sebagai sistem kendali. Mikrokontroler yang digunakan adalah Arduino Uno R3. Mikrokontroler ini menggunakan chip Atmega328P, dengan 14 digital pin I/O, 6 pin input analog, dan operasi tegangan 5 Volt [4].

\section{METODE}

Pada penelitian yang akan di uji yaitu diperlukan sebuah cara untuk penyelesaian terhadap implementasi suatu rancang bangun yang disusun secara struktur dan sistematis untuk melakukan penghalusan dan pencampuran kacang dengan air. 


\section{(Jurnal Teknologi Komputer dan Sistem Informasi)}

Februari 2021, Vol 1, No 1, Hlm. 1-7

Available online at http://jurnal.goretanpena.com/index.php/teknisi

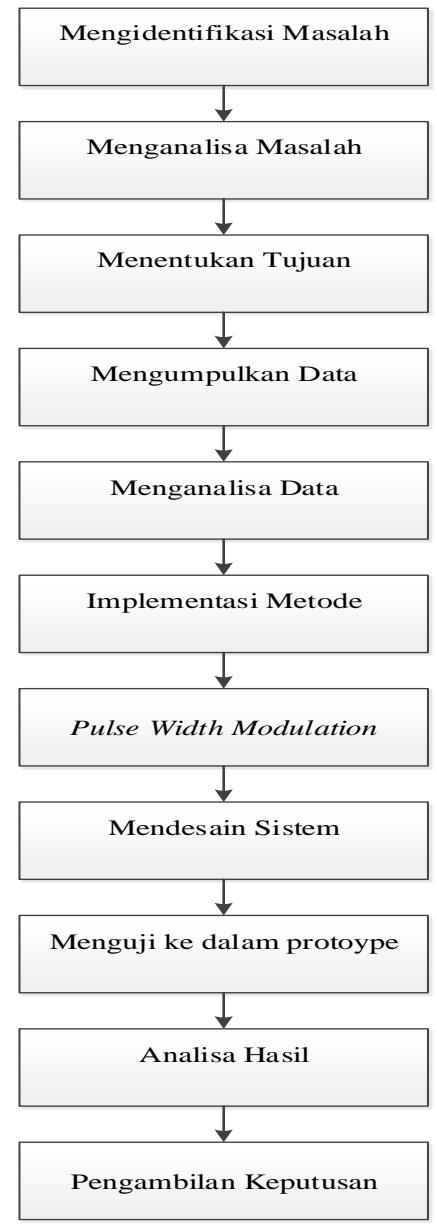

\section{HASIL DAN PEMBAHASAN}

Pada rangkaian perancangan sistem dibuat agar lebih mengetahui alat-alat apa saja yang dibutuhkan untuk membuat rangkaian pada sistem dan alat yang sudah jelas siap untuk di implementasikan.

\section{Rangkaian Load Cell}

Load cell adalah sebuah alat uji perangkat listrik yang dapat mengubah suatu energi menjadi energi lainnya yang biasa digunakan untuk mengubah suatu gaya menjadi sinyal listrik.

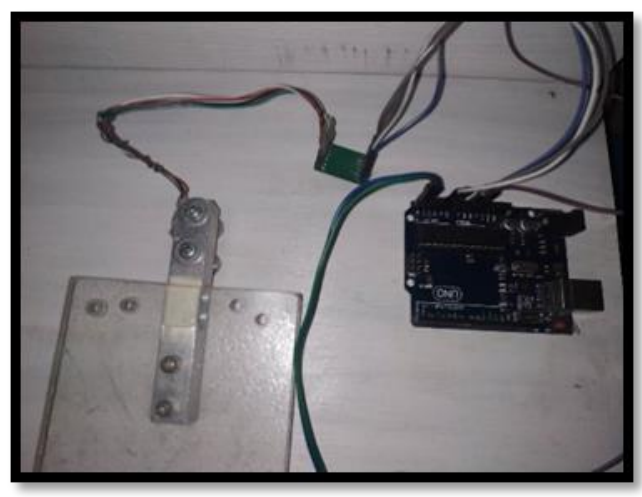

Gambar . Rangkaian Load Cell

\section{Rangkaian Arduino}

Arduino Uno adalah salah satu papan elektronika berbasis mikrokontroler atmega yang memiliki sistem minimum mikrokontroller dan juga memiliki 32 pin I/O. Arduino uno digunakan sebagai proses utama pada sistem blending kacang berbasis mikrokontroller dengan teknik PWM (Pulse Width Modulation).

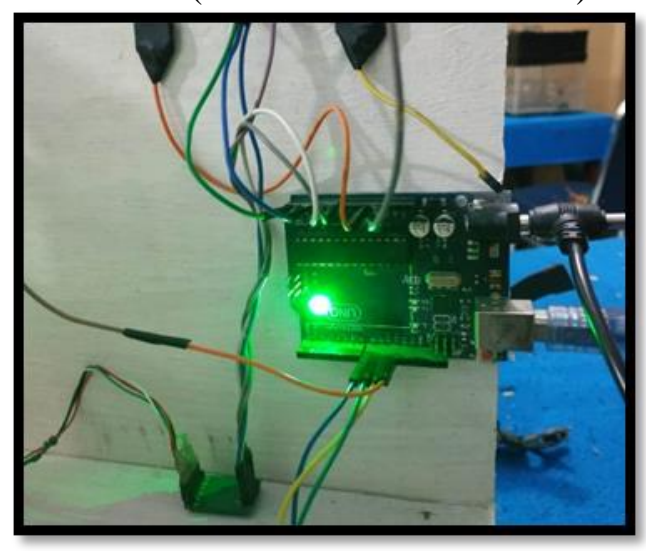

Gambar . Rangkaian Arduino Uno

merupakan gambar dari rangkaian Arduino Uno yang merupakan satu papan elektronika berbasis mikrokontroler atmega yang memiliki sistem minimum mikrokontroller dan juga memiliki 32 pin I/O. Arduino uno digunakan sebagai sistem kendali pada sistem blending kacang berbasis mikrokontroller dengan teknik PWM (Pulse Width Modulation).

\section{Rangkaian Blender}

rangkaian blender yang digunakan 


\section{(Jurnal Teknologi Komputer dan Sistem Informasi)}

Februari 2021, Vol 1, No 1, Hlm. 1-7

Available online at http://jurnal.goretanpena.com/index.php/teknisi

sebagai penghalus dan pencampur kacang dengan air. Terdapat 3 kondisi, yaitu; Low, Medium dan High, sehingga kita menggunakan 3 relay. Relay pertama untuk mengatur kecepatan Low dihubungkan ke pin 8 pada Arduino, relay kedua untuk mengatur kecepatan Medium dihubungkan pada pin 9 pada Arduino, serta relay 3 dihubungkan ke pin 10 pada Arduino sebagai pengatur kecepatan High.

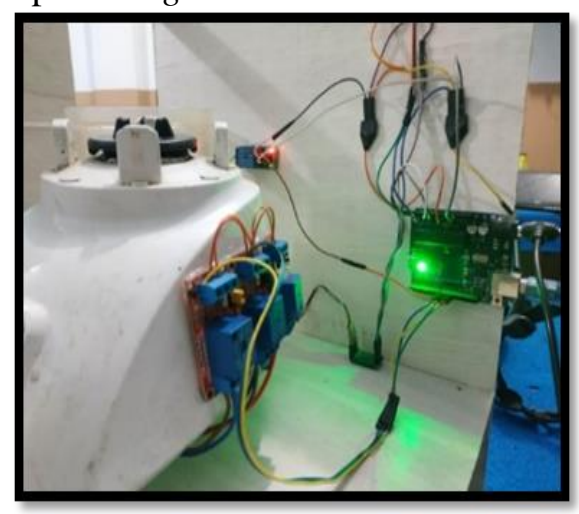

Gambar . Rangkaian Blender

\section{Rangkaian Pompa Air DC}

Rangkaian dari pompa air DC yang digunakan sebagai pengalir air ke wadah blender di atasnya sebelum blender mulai bekerja, sehingga kerja blender untuk menghaluskan kacang lebih mudah. Pompa DC pada sistem dihubungkan ke relay yang disteruskan ke pin 11 pada Arduino Uno dan Gound dan VCC pada pinnya masing-masing di Arduino.

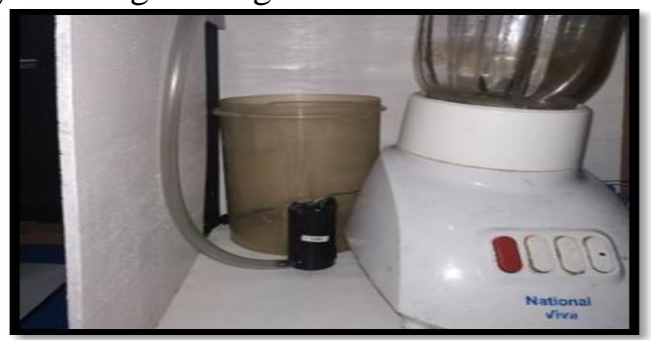

Gambar . Rangkaian Pompa Air DC

\section{Rangkaian LCD}

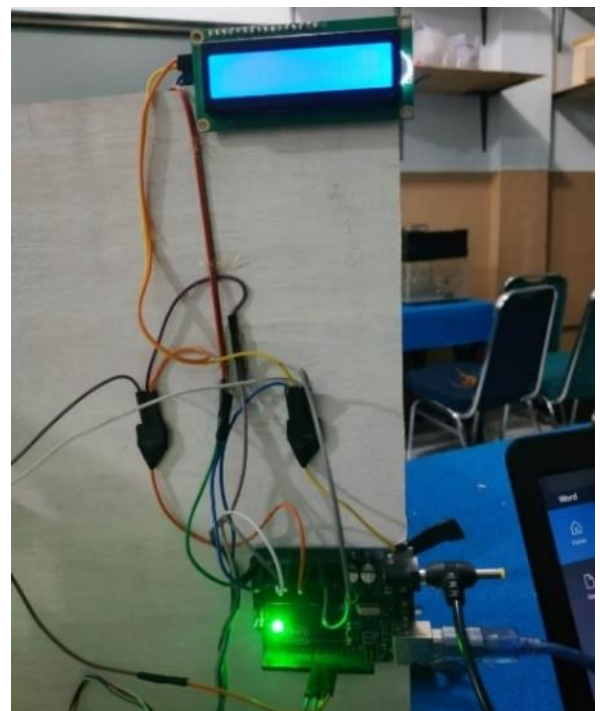

Gambar. Rangkaian LCD

Rangkaian LCD yang telah dihubungkan dengan sistem kendali mikrokontroler Arduino uno. Pin SCL pada LCD dihubungkan ke pin A5 pada arduino kemudian pin SDA dihubungkan ke pin A4. LCD ini berfungsi sebagai display untuk memberitahukan berat kacang dan nyala blender.

\section{Rangkaian Keseluruhan}

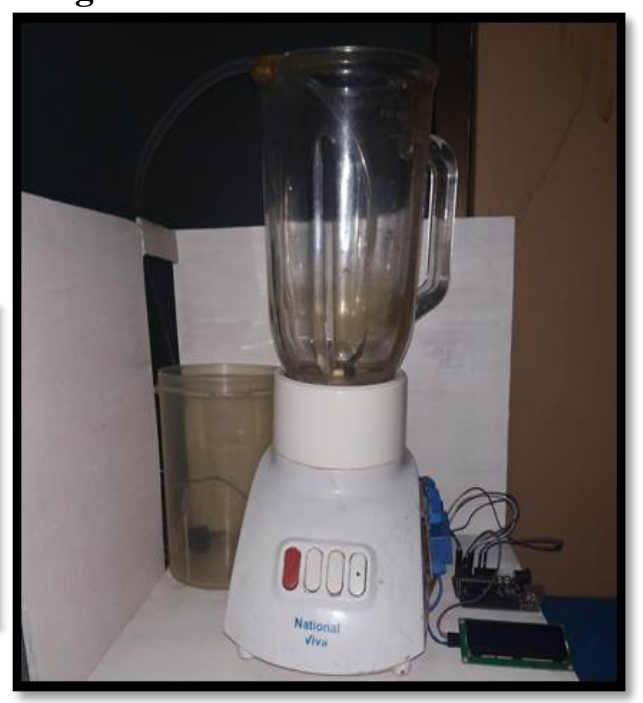

Gambar . Rangkaian Keseluruhan

Pada gambar diatas merupakan gambar dari keseluruhan sistem kendali dan rangkaian model lainnya, seperti dari rangkain sensor Load cell sebagai 


\section{(Jurnal Teknologi Komputer dan Sistem Informasi)}

Februari 2021, Vol 1, No 1, Hlm. 1-7

Available online at http://jurnal.goretanpena.com/index.php/teknisi

inputan yang berada dibawah blender, kemudian rangkaian blender yang sudah dihubungkan ke relay, lalu rangakaian pompa air DC yang difungsikan sebagai pengalir air dan rangkaian LDC sebagai output display.

\section{Pengujian Catu Daya}

Pengujian catu daya dilakukan juga untuk menguji kestabilan dari sistem. Fungsi utama catu daya yaitu sebagai penyuplai daya untuk mengaktifkan komponen-komponen elektronika yang digunakan. Dengan adanya catu daya sistem dapat digunakan secara stabil.

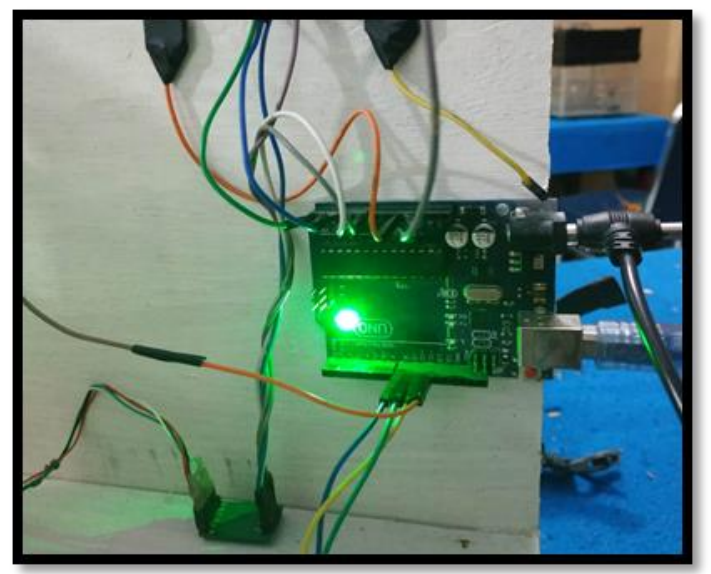

Gambar 9. Pengujian Catu Daya

\section{Pengujian Load Cell dan Blender}

Pengujian teknik Pulse Width Modulation (PWM) sebagai pengatur kecepatan putar blender. Pengujian ini dilakukan untuk mengatur kecepatan putaran motor dengan menyesuaikan beban kacang dalam wadah blender.

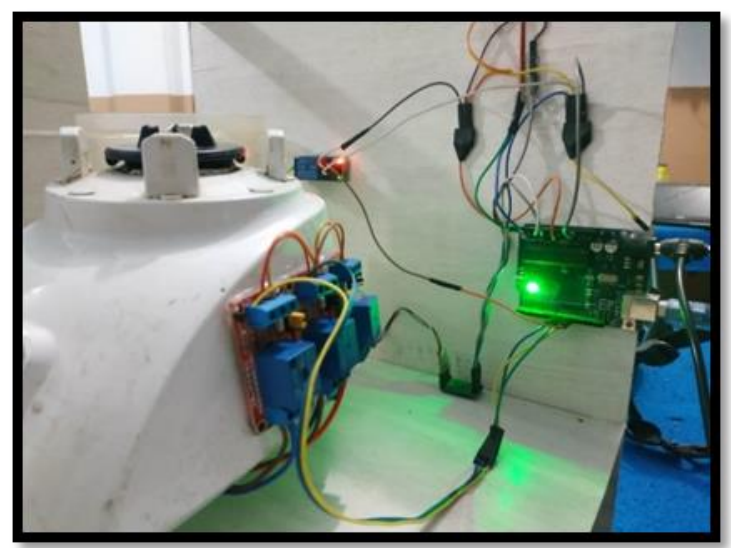

Gambar 10. Pengujian Sensor Load Cell dan Blender

\section{Pengujian LCD}

Pengujian LCD pada sistem untuk mengetahui kinerja display dapat berfungsi dengan baik, karena LCD pada sistem ini cukup penting sebagai penampil berat beban dalam wadah yang terdeteksi oleh sensor.

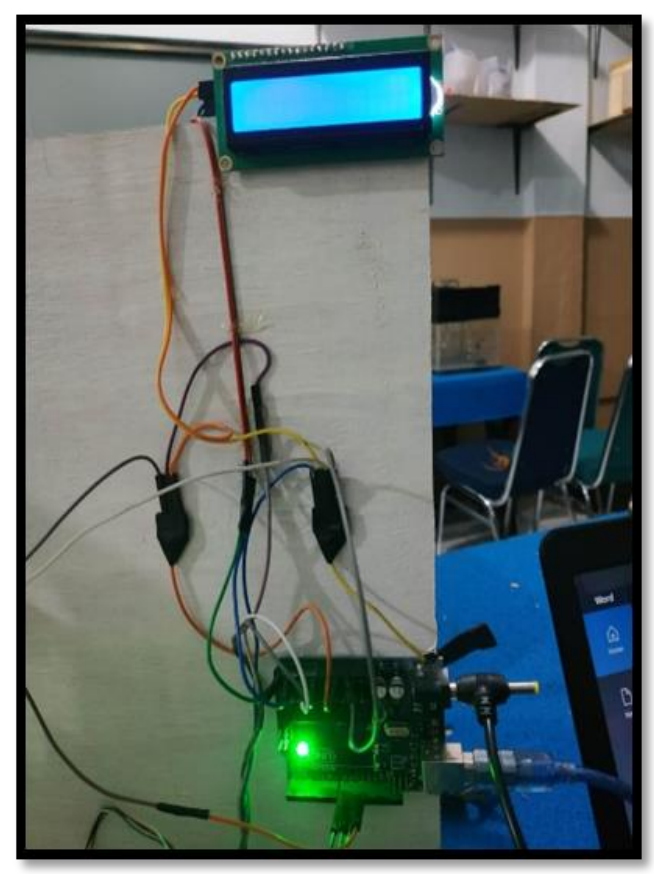

Gambar 11. Pengujian LCD

\section{Pengujian Seluruh Sistem}

Setelah melakukan pengujian terhadap masing-masing komponen pada 


\section{(Jurnal Teknologi Komputer dan Sistem Informasi)}

Februari 2021, Vol 1, No 1, Hlm. 1-7

Available online at http://jurnal.goretanpena.com/index.php/teknisi

sistem blending kacang ini, maka selanjutnya dilakukanlah sebuah pengujian secara keseluruhan system untuk mendapatkan hasil yang diinginkan.

\begin{tabular}{|l|c|c|c|}
\hline No & Duty Cycle (PWM) & Level Putaran Motor & Ukuran Berat \\
\hline 1 & $30 \%$ & Low & $>$ lons \\
\hline 2 & $50 \%$ & Medium & $>2$ ons \\
\hline 3 & $80 \%$ & High & $>30 n s$ \\
\hline
\end{tabular}

\section{SIMPULAN}

Adapun kesimpulan yang dapat diambil dari penerapan Pulse Width Modulation (PWM) pada sistem blending kacang ini adalah sebagai berikut :

1. Dalam membangun perancangan sistem blending kacang ini pertama yang harus dilakukan adalah design sistem terlebih dahulu kedalam bentuk 3D atau prototype. Hal ini bertujuan untuk menentukan konsep sistem blending dan bagaimana bentuk prototype yang diinginkan.

2. Sebelum sistem blending kacang ini diimplementasikan kedalam konsep Pulse Width Modulation (PWM) yang berbasis Mikrokontroler Arduino hal yang harus dilakukan terlebih dahulu adalah dengan menentukan komponenkomponen elektronika apa saja yang digunakan kemudian komponen tersebut disatukan menjadi satu rangkaian dengan menggunakan papan pcb yang nantinya rangkaian tersebut dapat mempermudah dalam menghubungkan antara satu rangkaian dengan rangkaian lainnya.

3. Melakukan dan memasukkan kode pemrograman pada sistem kendali Arduino Uno. Hal ini bertujuan untuk menguji apakah rangkaian tersebut berjalan sesuai dengan kode program yang telah dimasukkan.

4. Menguji sistem secara keseluruhan dengan melakukan simulasi penghalusan dan pencampuran kacang dengan air yang sedang berlangsung pada rancang bangun prototype.

5. Setelah menguji perancangan sistem blending kacang menggunakan konsep Pulse Width Modulation (PWM) berbasis Arduino Uno secara keseluruhan pada prototype, diharapkan sistem ini diimplementasikan secara langsung dan dapat membantu meringankan pekerjaan pedagang ataupun koki nantinya.

\section{DAFTAR PUSTAKA}

[1] Anggraeni, D. H., Saputra, R., \& Noranita, B. (2013). Aplikasi Data Mining Analisis Data Transaksi Penjualan Obat Menggunakan Algoritma Apriori (Studi Kasus di Apotek Setya Sehat Semarang). Data mining. 2(2), 1-7.

[2] Azwar, A. (2015). Algorithm Apriori Use for a Consumer Behavior in. Sains Dan Informatika, 1, 45-59.

[3] F. A. Hermawati, DATA MINING, I. Yogyakarta: Andi, 2013.

[4] F. A. Sianturi et al. (2019). Data Mining Teori dan Aplikasi Weka:CV.Rudang Mayang. Medan.

[5] Haryanto, D., Oslan, Y., \& Dwiyana, D. (2011). Implementasi Analisis Keranjang Belanja Dengan Aturan Asosiasi Menggunakan Algoritma Apriori Pada Penjualan Suku Cadang Motor. Jurnal Buana Informatika, 2(2), 81-94. https://doi.org/10.24002/jbi.v2i2.311

[6] Ii, B. A. B. (2005). Data Mining Data mining. Mining of Massive Datasets, 2(January 2013), 5-20. https://doi.org/10.1017/CBO978113 9058452.002

[7] Kristalia, A., Praja, E., Mandala, W., Kom, S., Kom, M., \& Permana, R. (2014). Aplikasi Data Mining Menggunakan Aturan Asosiasi Mini Market Orchard. Eprint, 1-10.

[8] Listriani, D., Setyaningrum, A. H., \& M.A, F. E. (2016). Penerapan Metode Asosiasi Menggunakan 


\section{(Jurnal Teknologi Komputer dan Sistem Informasi)}

Februari 2021, Vol 1, No 1, Hlm. 1-7

Available online at http://jurnal.goretanpena.com/index.php/teknisi

Algoritma Apriori Pada Aplikasi Pola Belanja Konsumen ( Studi Kasus Toko Buku Gramedia Bintaro ). Jurnal Teknik Informatika Vol 9 No. 2, Universitas Islam Negeri Jakarta, 9(2), 120-127. Retrieved from

http://journal.uinjkt.ac.id/index.php/t i/article/view/5602/3619

[9] Meiwati, L., Sistem, J., Fakultas, I., Gunadarma, U., Mustikasari, M., Sistem, J., Fakultas, I., \& Gunadarma, U. (n.d.). APLIKASI DATA MINING MENGGUNAKAN ATURAN ASOSIASI.

[10] R.AS and M.Shalahuddin, Rekayasa Perangkat Lunak, Terstruktur dan berorientasi objek, Bandung, Indonesia: Penerbit Informatika, 2014.

[11] Riandari, F., \& Simangunsong, A. (2019). Penerapan Algoritma C4.5 Untuk Mengukur Tingkat Kepuasan Mahasiswa. Terakreditasi DIKTI, $3(2), 1-7$

[12] Riszky, A. R., \& Sadikin, M. (2019). Data Mining Menggunakan

Algoritma Apriori untuk

Rekomendasi Produk bagi Pelanggan. Jurnal Teknologi Dan

Sistem Komputer, 7(3), 103-108.

https://doi.org/10.14710/jtsiskom.7. 3.2019.103-108

[13] R.T Vulandari, Data Mining, Teori dan Aplikasi Rapidminer, Cetakan I,. Surakarta: PENERBIT GAVA MEDIA, 2018.

[14] Sari, P., \& Sinaga, B. (2018). 9. Aplikasi Data Mining Dengan Menggunakan Algoritma Apriori Untuk Penjualan Produk Terbesar Pada Cv. Sakura Photo. EJurnal.Pelitanusantara.Ac.Id, 22(1), 34-38. Retrieved from http://ejurnal.pelitanusantara.ac.id/index.ph $\mathrm{p} / \mathrm{mantik} /$ article/view/349

[15] Wijayanti, A. W. (2017). Analisis Hasil Implementasi Data Mining
Menggunakan Algoritma Apriori pada Apotek. Jurnal Edukasi Dan Penelitian Informatika (JEPIN), 3(1), 60. https://doi.org/10.26418/jp.v3i1.195 $\underline{34}$ 